\title{
PENGARUH MENTORING DOSEN PEMBIMBING AKADEMIK TERHADAP PRESTASI AKADEMIK MAHASISWA
}

\author{
Fransisca Desiana Pranatasari \\ Universitas Ciputra Surabaya \\ fransisca.desiana@ciputra.ac.id
}

\begin{abstract}
The main tasks of lecturers in education is mentoring. Topics mentoring can be anything, including the related to their academic achievement. This research is the development of previously conducted research using a qualitative approach to sample 5 student informants. The study resulted in the finding that the lecturer's role as a mentor is needed in the educational environment entepreneurship. The aim of this study was conducted to see mentoring influence lecturer with student achievement increased done with quantitative approach. Data was collected using purposive sampling. The criteria used is minimal student academic mentoring activities three times in the first half had been a student with a minimum of 1 year and students are students majoring in Management University Ciputra. The result mentoring has a positive influence on students' academic achievement as students are encouraged to get the best value according to their targets.

Keywords: mentoring, student academic achievement, entrepreneurship, education environment
\end{abstract}

\begin{abstract}
ABSTRAK
Salah satu tugas utama dosen dalam dunia pendidikan adalah melakukan mentoring. Topik mentoring bisa apa saja, termasuk didalamnya adalah berkaitan dengan pencapaian akademik mereka. Tugas ini telah lama kurang menjadi sorotan dan fokus utama dosen sehingga mahasiswa bebas mengkontrak mata kuliah tanpa sepengatahuan dosennya. Akibat terburuknya adalah terjadi keterlambatan kelulusan yang menyebabkan kerugian bagi pemerintah. Penelitian ini merupakan penelitian pengembangan yang sebelumnya dilakukan peneliti menggunakan pendekatan kualitatif dengan sampel 5 informan mahasiswa. Penelitian tersebut menghasilkan temuan bahwa peran dosen sebagai mentor sangat dibutuhkan di lingkungan pendidikan entepreneurship. Penelitian kali ini dilakukan dengan tujuan untuk mendapatkan melihat lebih dalam pengaruh mentoring dosen sehingga prestasi mahasiswa semakin meningkat yang dilakukan dengan pendekatan kuantitatif. Teknik pengumpulan data dilakukan dengan metode purposive sampling dengan jumlah 275 mahasiswa. Adapun kriteria yang digunakan yaitu mahasiswa minimal melakukan kegiatan mentoring akademik 3 kali dalam 1 semester dengan minimal telah menjadi mahasiswa selama 1 tahun serta mahasiswa merupakan mahasiswa jurusan Manajemen Universitas Ciputra. Hasilnya mentoring memiliki pengaruh positif terhadap prestasi akademik mahasiswa karena mahasiswa terpacu untuk mendapatkan nilai terbaik sesuai dengan target mereka.

Kata kunci: mentoring, prestasi mahasiswa, entrepreneurship, lingkungan pendidikan
\end{abstract}

\section{PENDAHULUAN}

Tugas utama dosen selalu identik dengan istilah tri dharma perguruan tinggi yaitupeengajaran, penelitian, dan pengabdian masyarakat. Saat memutuskan menjadi seorang dosen, tugas ini otomatis melekat pada dirinya. Sejak awal memulai karirnya sebagai dosen, biasanya jadwal pengajaran sudah harus dilakukan setiap harinya sesuai dengan kemampuan masingmasing. Penelitian dan pengabdian masyarakat juga dilakukan setiap dosen berdasarkan bidang keahliannya. Ada satu tugas lagi yang sedikit dilupakan sebagai tugas utama dosen yaitu dosen sebagai wali mahasiswaa. Di jenjang perguruan tinggi, wali murid dikenal dengan istilah dosen pembimbing akademik (selanjutnya menggunakan singkatan dosen PA). Menurut Kementrian Pendidikan dan Kebudayaan (2014) menyatakan bahwa penasihat akademik atau dosen wali memiliki tugas untuk melakukan bimbingan kepada mahasiswa dalam 
kaitannya dengan kegiatan akademik selama menempuh studi program dengan perincian tugas yang akan ditetapkan oleh masing-masing perguruan tinggi dalam peraturan akademiknya. Dengan adanya dosen pembimbing akademik diharapkan mahasiswa dapat lulus sesuai dengan target mereka atau tepat waktu. Keterlambatan kelulusan mahasiswa ternyata juga berdampak buruk untuk pemerintah, karena subsidi untuk pendidikan mahasiswa yang terlambat lulus di Indonesia mencapai 8 triliun rupiah (Kaltim Post, 2012).

Tabel 1. Rekap Nasional Perguruan Tinggi Semester 2014/2015 Genap

\begin{tabular}{|c|c|c|c|c|c|c|c|c|c|}
\hline \multicolumn{4}{|c|}{ Perguruan Tinggi } & \multicolumn{3}{|c|}{ Mahasiswa } & \multicolumn{3}{|c|}{ Dosen } \\
\hline & Negeri & Swasta & Total & Negeri & Swasta & Total & Negeri & Swasta & Total \\
\hline PT & 121 & 2,997 & 3,118 & $2,155,483$ & $4,289,865$ & $6,445,348$ & 70,239 & 139,097 & 209,336 \\
\hline PTA & 71 & 911 & 982 & 262,336 & 42,227 & 304,563 & 9,798 & 4,791 & 14,589 \\
\hline PTK & 172 & 0 & 172 & 104,662 & 0 & 104,662 & 9,097 & 0 & 9,097 \\
\hline Total & 364 & 3,908 & 4,272 & $2,522,481$ & $4,332,092$ & $6,854,573$ & 89,134 & 143,888 & 233,022 \\
\hline
\end{tabular}
(sumber: http://forlap.dikti.go.id/, 2015)

Berdasarkan penelitian yang dilakukan oleh Ackerman dan Gross (2005) didapatkan bahwa penyebab keterlambatan kelulusan mahasiswa diperngaruhi beberapa faktor yaitu defisiensi regulasi diri, motivasi yang rendah, pusat kendali diri eksternal, perfeksionis, dan manajemen waktu yang lemah. Dengan demikian, untuk mengendalikan faktor tersebut peran dosen PA sangat diperlukan.

Peran dosen PA untuk perguruan tinggi berbasis entrepreneurship sedikit berbeda dengan perguruan tinggi lainnya. Pada perguruan tinggi berbasis entrepreneurship mahasiswa melaksanakan sebuah proyek bisnis bersamaan dengan perkuliahan. Biasanya mahasiswa yang lemah dalam melakukan manajemen waktu akan kewalahan ditahapan ini sehingga nilainya akan turun terus menerus. Akibatnya mereka terlambat dalam mencapai kelulusan. Dengan demikian peran dosen PA untuk memonitor perkembangan mahasiswa sangat diperlukan disini. Peran mentoring menurut Crisp dan Cruz (2009) yaitu dilakukan dari perspektif psikologis, perspektif bisnis, dan perspektif akademik. Menurut Taylor, et al (2009), mentor harus menunjukan beberapa fungsi kepada mentee yaitu dukungan psikologis dan emosional, bantuan langsung untuk pengembangan karir dan profesional, dan role model. Dalam penelitian yang dilakukan di lingkungan pendidikan ini, fungsi bantuan langsung untuk pengembangan karir dan professional disesuaikan menjadi bantuan langsung untuk pengembangan akademik mahasiswa. 
Perguruan tinggi berbasis entrepreneurship sudah cukup banyak di Indonesia, sebagai contoh yaitu Universitas Ciputra. Sejak tahun 2006, Universitas Ciputra membangun sebuah pembelajaran berbasis entrepreneurship yang dikemas dalam kurikulum berkelanjutan untuk mahasiswa semester 1 hingga 8. Dimana masing-masing semester terdapat mata kuliah entrepreneurship yang dipakai untuk melaksanakan proyek bisnis. Untuk melakukan keseimbangan antara mata kuliah mayor yang mahasiswa ambil sesuai dengan fakultas masing-masing dengan mata kuliah entrepreneurship, maka Universitas Ciputra mendelegasikan dosen untuk menjadi dosen PA bagi beberapa mahasiswa. Peran dosen PA yang dapat memonitor perkembangan akademik mahasiswa tersebut agar dapat mencapai prestasi akademik sesuai dengan kemampuan masing-masing mahasiswa, sehingga yang menjadi rumusan masalah dalam penelitian ini adalah:

Bagaimanakah sebaiknya dukungan psikologis dan emosional, bantuan langsung pengembangan akademik, dan role model dosen PA di lingkungan pendidikan entreprenership?

Bagaimanakah prestasi akademik mahasiswa di lingkungan pendidikan entrepreneurship?

Apakah terdapat pengaruh dukungan psikologis dan emosional dosen PA terhadap prestasi akademik mahasiswa?
Apakah terdapat pengaruh bantuan langsung pengembangan akademik dosen PA terhadap prestasi akademik mahasiswa?

Apakah terdapat pengaruh role model dosen PA terhadap prestasi akademik mahasiswa?

Penelitian ini dilakukan dengan tujuan untuk mengetahui bahwa Peran dosen PA sangatlah penting bagi perkembangan prestasi mahasiswa khususnya untuk perguruan tinggi berbasis entrepreneurship. Banyak faktor yang bisa membuat mereka tidak lulus tepat waktu sehingga dosen PA perlu mendukung mereka melalui kegiatan mentoring akademik yang diharapkan dapat memotivasi mereka dalam mencapai target mereka masing-masing. Kegiatan mentoring dalam bentuk dukungan psikologis dan emosional, bantuan langsung pengembangan akademik, dan role model diharapkan membawa mahasiswa mendapatkan prestasi akademik sesuai dengan target mereka. Penelitian ini dilakukan sebagai wujud evaluasi pelaksanaan mentoring dosen pembimbing akademik (dosen PA) terhadap mahasiswanya. Hal ini didasari oleh fenomena bahwa kebannyakan perguruan tinggi kurang melaksanakan peran dosen wali seperti peran guru wali di bangku sekolah (TK sampai SMA), padahal peran tersebut sangat penting untuk perkembangan mahasiswa baik secara akademik maupun secara personal. 


\section{TINJAUAN PUSTAKA}

\section{Entrepreneurship}

Sebuah negara sangat memerlukan entrepreneur untuk memajukan negaranya menjadi negara maju.Untuk menciptakan lebih banyak entrepreneur, pendidikan juga memiliki peran didalamnya. Menurut Suryana (2013) kewirausahaan (entrepreneurship) adalah suatu disiplin ilmu yang mempelajari tentang nilai, juga kemampuan, serta perilaku seseorang dalam menghadapi tantangan untuk memperoleh peluang dengan berpikir kreatif dan inovatif. Fungsi entrepreneur adalah mengubah pola produksi dengan jalan memanfaatkan sebuah penemuan baru untuk kemungkinan produksi komoditi baru sehingga terbentuk sebuah industry baru (Winardi, 2003).

Pendidikan

Entrepreneurship merupakan suatu metode pembelajaran yang secara komprehensif menggabungkan pembelajaran jurusan tertentu dengan pengalaman berbisnis. Universitas Ciputra merupakan salah satu contoh perguruan tinggi yang melaksanakan pembelajaran berbasis entrepreneurship. Dalam rangka menjaga keseimbangan antara mata kuliah mayor yang mahasiswa ambil sesuai dengan fakultas masing-masing dengan mata kuliah entrepreneurship, maka Universitas Ciputra mendelegasikan dosen untuk menjadi dosen PA bagi beberapa mahasiswa. Dengan demikian diharapkan perhatian dosen PA melalui mentoring akademik yang dilakukan setiap semester dapat memotivasi mahasiswa untuk meraih prestasinya dan lulus sesuai dengan target masing-masing.

Dalam pendidikan entrepreneur, proses pembelajaran melibatkan pengembangan bisnis yang terprogram secara bersinergi dengan pendidikan secara akademik (Sullivan, 2000). Pembelajarannya dilakukan secara komprehensif antara ketrampilan, kebiasaan, pengetahuan, dan etika berperilaku (Sullivan, 2000).

\section{Prestasi Mahasiswa}

Menurut (Simon dan Cyrenne, 2008) terdapat empat indikator seorang mahasiswa dapat gagal secara akademik, yaitu karena takut gagal dan turunnya motivasi akademik. Perkembangan akademik mahasiswa dapat diukur melalui Indeks Prestasi (IP) Akademik yang didapatkan mereka per semester maupun kumulatif. Selain itu, perkembangan mereka dapat dilihat melalui kelancaran mereka dalam studi yang diukur sesuai dengan kemampuan masing-masing mahasiswa.

Menurut Plecha dalam penelitian yang dilakukan oleh Komarajju, et al (2010), banyak ahli yang menemukan bahwa pembicaraan yang semakin sering antara fakultas dan mahasiswa diluar kelas dan menerima nasihat-nasihat tentang program belajar mereka, berdampak signifikan dengan peningkatan prestasi dan kepercayaan diri mereka. Hal ini terbukti dapat mengikat mahasiswa secara akademik sehingga mereka terlibat aktif 
untuk melakukan lebih baik demi pengembangan akademiknya dan fakultas.

Kesuksesan sebuah program mentoring tidak hanya diukur melalui prestasi akademik mahasiswa/mentee saja tetapi juga peningkatan kepercayadirian mahasiswa/mentee (Saliniti, 2005). Beberapa institusi pendidikan, prestasi mahasiswa sudah mulai dibangun melalui program mentoring sejak tahun pertama mahasiswa melakukan pembelajaran di bangku perguruan tinggi untuk menentukan capaian yang ingin diraih mahasiswa tersebut hingga sampai pada kelulusan nanti (Saliniti, 2005).

\section{Mentoring}

Kegiatan mentoring dilaksanakan seorang fasilitator sebagai pengarah cara untuk mengikuti sasaran sesuai dengan ketetapan seorang fasilitator. Menurut Sumpeno (2009:102) mentoring dilakukan untuk membuka potensi yang tersembunyi, menelisuri kemampuan dasar seseorang, dan mengingatkan sesorang untuk sadar akan tujuan yang ingin dicapainya. Sebaiknya seorang fasilitator mengawali kegiatan mentoring dengan menanyakan potensi yang dimiliki bukan menetapkan target yang harus dicapai. Mentor merupakan orang yang melakukan kegiatan mentoring kepada mentee, dalam hal ini mentor adalah dosen. Mentee adalah pihak yang menerima nasihat dan target mentoring.

Menurut Flaherty (2011:3) mentoring adalah sebuah kegiatan untuk mendukung seseorang dalam mencapai tujuan atau mengubah seseorang untuk melakukan tindakan tertentu. Kegiatan mentoring ini dilakukan juga untuk menjaga motivasi seseorang yang dimentor. Motivasi adalah sebuah kondisi yang menggerakkan manusia untuk mencapai tujuan (Sumpeno, 2009:117). Menurut Thompson dan Vance (2001), terdapat dua tipe mentoring, yaitu mentoring yang natural dan mentoring yang direncanakan. Mentoring yang natural (informal) biasanya terjadi melalui proses pertemanan, pengajaran, dan konseling. Interaksi secara informal sangat penting untuk mempengaruhi etika mahasiswa dalam berperilaku, meningkatkan motivasi, mengikat, dan menularkan nilai fakultas (Thompson dan Vance, 2001). Mentoring yang direncanakan biasanya lebih sistematis karena secara sengaja dibuat untuk tujuan tertentu dalam proses formal (Thompson dan Vance, 2001).

Karakteristik mentor yang baik menurut Cook dan Poole (2011:19) adalah positive, enthusiastic, trusting, focused, sees the big picture, observant, respectful, patient, clear, curious, dan objective. Seorang mentor dapat menjadi mentor yang efektif bila mampu mengelola waktu, energi, tujuan, informasi yang akurat dan perhatian (Cook dan Poole,2011:133).

Evaluasi program mentoring sangat penting untuk menentukan efektivitas dari solusi yang ditawarkan (Thompson dan Vance, 2001). Mentoring yang efektif dapat diukur pula melalui laporan individu pihak yang dimentor (mentee). Menurut Crips dan 
Cruz (2009) evaluasi mentoring dapat dilihat dari 3 perspektif yaitu bisnis, psikologis, dan pendidikan. Fungsi mentoring menurut Crips dan Cruz (2009) yaitu dukungan psikologi dan emosional, bantuan untuk perencanaan tujuan, dukungan pengetahuan akademik mahasiswa dan role model. Yang tergambarkan dalam fungsi mentoring psikologis dan emosional adalah seni mendengarkan, memberikan dukungan moral, identifikasi masalah dan memberikan dorongan, dan memberikan hubungan yang suportif (Crips dan Cruz, 2009).

Dalam memberikan dukungan untuk pilihan akademik mahasiswa, mentor mampu mempresentasikan atas mahasiswa mengenai kekuatan, kelemahan, kemampuan mereka serta mendukung pembuatan perencanaan tujuan pencapaian akademik masing-masing mahasiswa (Crips dan Cruz, 2009). Dalam fungsi ini, mentor melakukan eksplorasi ketertarikan, kemampuan, dan kepercayaan mahasiswa berkaitan dengan akademik mereka.

"Mentoring was described by several of the respondents as a series of focused or "strategic" interactions with various individuals about specific professional issues, rather than a formal, longitudinal relationship. We propose the term "strategic mentorship" for this new variant" (Taylor, et al, 2009).

Dukungan untuk pengetahuan akademik mahasiswa identik dengan hubungan mahasiswa dalam kelas secara formal untuk peningkatan pengetahuan dan ketrampilan (Crips dan Cruz, 2009).

Fungsi role model ini dirasakan mentee untuk belajar pengalaman mentor dalam mencapai keberhasilan dan kegagalan secara personal untuk memotivasi mentee sehingga mentor dijadikan panutan/ role model oleh mentee (Crips dan Cruz, 2009). Role model adalah metode yang efektif untuk menginspirasi seseorang membangun ketrampilan dan kemampuan mentee (Taylor, et al, 2009).

"A "role model" has been defined as a "person whose behavior in a particular role is imitated by others". Role models can have a powerful effect on students and residents in training" (Taylor, et al, 2009).

\section{Kerangka Pemikiran}

Peran dosen PA sangat penting bagi perkembangan prestasi mahasiswa terutama mereka yang memiliki masalah dalam beberapa hal seperti motivasi, manajemen waktu, dan sebagainya. Bila seorang mahasiswa hanya dibiarkan saja tanpa didampingi secara personal selama satu semester mungkin saja dia tidak memiliki arah untuk mengembangkan diri sesuai dengan porsi masing-masing. Dengan melakukan personal mentoring setiap sementer minimal 3 kali diharapkan mahasiswa dapat terarah dalam mencapai target mereka masing-masing. Menurut Crips dan Cruz (2009), mentoring dapat dilakukan dengan perpektif psikologis, bisnis dan akademik. Penelitian ini dikemukakan juga oleh Taylor, et al (2009), 
bahwa fungsi mentoring yaitu sebagai

model. Hal tersebut dijelaskan lewat dukungan psikologis dan emosional, gambar sebagai berikut:

bantuan pengembangan akademik dan role

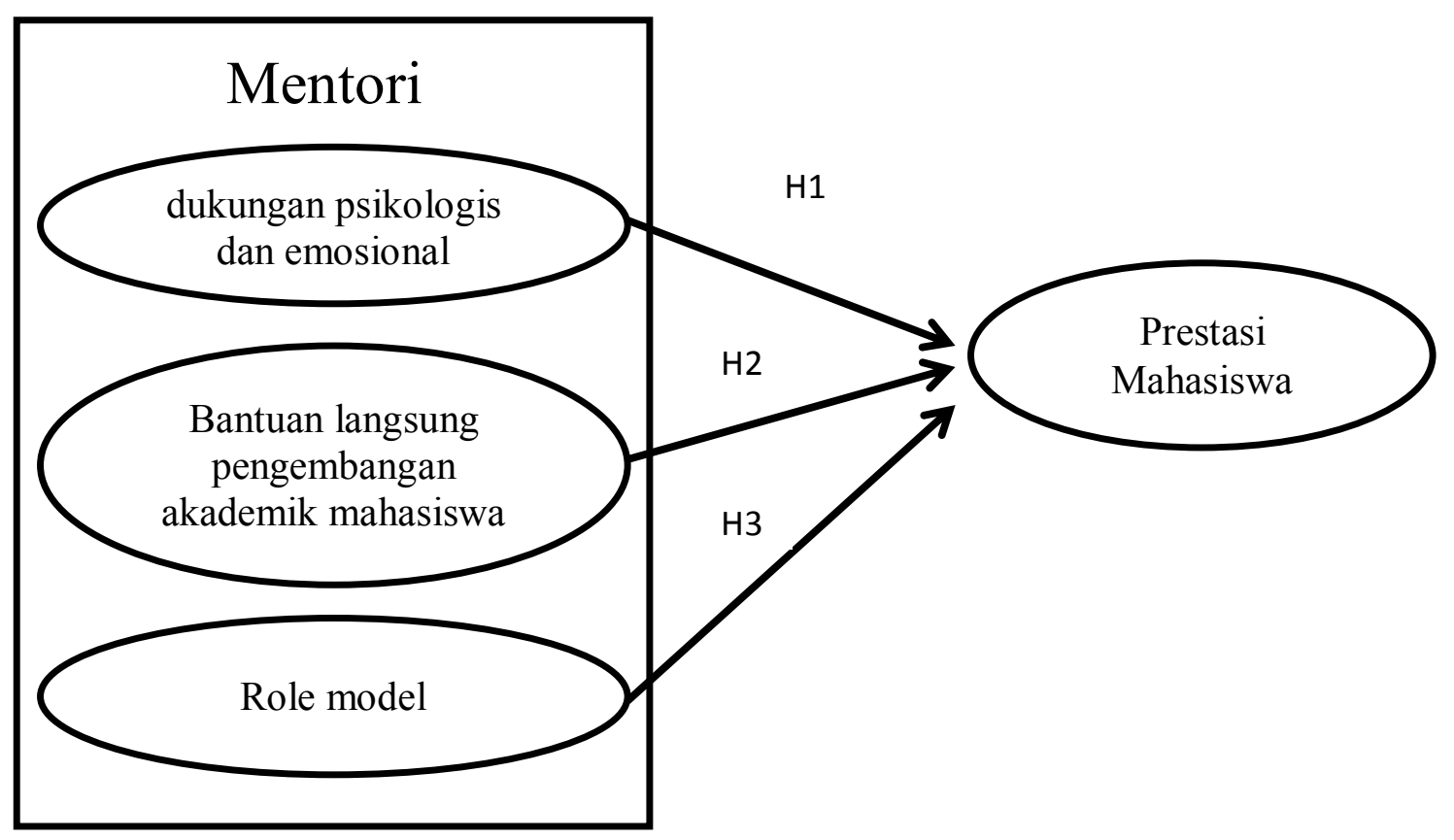

Gambar 1 Skema Kerangka Pemikiran

\section{Definisi Operasional}

Dalam lingkungan pendidikan entrepreneurship, peran mentoring sangat penting untuk perkembangan mahasiswa, terutama dosen PA. Peran dosen PA dimulai sejak tahun pertama mahasiswa masuk ke perguruan tinggi hingga mereka dinyatakan lulus nantinya. Hal ini berguna untuk meningkatkan rasa percaya diri mereka, pengetahuan akan pencapaian dan target pembelajaran di perguruan tinggi hingga masalah personal yang mungkin akan menghambat motivasi mereka dalam berprestasi sesuai dengan kemampuan mereka.
Fungsi mentoring yang utama untuk meningkatkan pretasi mereka adalah dukungan psikologis dan emosional, bantuan langsung pengembangan akademik mahasiswa, dan sebagai role model (Taylor, et al, 2009). 
Tabel 2. Variabel, Indikator, dan SkalaUkur

\begin{tabular}{|c|c|c|c|c|}
\hline Landasan Teori & Variabel & $\begin{array}{l}\text { Dimensi/Sub } \\
\text {-variabel }\end{array}$ & Indikator & Skala Ukur \\
\hline \multirow{2}{*}{$\begin{array}{l}\text { Prestasi mahasiswa } \\
\text { sudah mulai } \\
\text { dibangun melalui } \\
\text { program mentoring } \\
\text { sejak tahun pertama } \\
\text { mahasiswa } \\
\text { melakukan } \\
\text { pembelajaran di } \\
\text { bangku perguruan } \\
\text { tinggi untuk } \\
\text { menentukan } \\
\text { capaian yang ingin } \\
\text { diraih mahasiswa } \\
\text { tersebut hingga } \\
\text { sampai pada } \\
\text { kelulusan nanti } \\
\text { (Saliniti, 2005). }\end{array}$} & \multirow{2}{*}{\multicolumn{2}{|c|}{ Prestasi Mahasiswa }} & $\begin{array}{ll}\text { - } & \text { Nilai rata-rata } \\
& \text { Entrepreneurship } 3 \\
\text { - } & \text { Nilai rata-rata } \\
& \text { Entrepreneurship } 5 \\
\text { - } & \text { Nilai rata-rata } \\
& \text { Entrepreneurship Project } 3 \\
\text { - } & \text { Nilai rata-rata } \\
& \text { Entrepreneurship Project } 5 \\
\text { - } & \text { Nilai rata-rata } \\
& \text { Entrepreneurship Project } 7\end{array}$ & Skala Interval \\
\hline & & & $\begin{array}{ll}- & \text { Nilai rata-rata sesuai } \\
& \text { harapan } \\
\text { - } & \text { IPK diatas } 3 \\
\text { - } & \text { Target lulus 3,5 th } \\
\text { - } & \text { Tidak masalah melakukan } \\
\text { bisnis bersamaan dengan } \\
\text { kuliah }\end{array}$ & $\begin{array}{l}\text { Skala Likert } \\
1: \text { STS } \\
2: \text { TS } \\
3: \mathrm{N} \\
4: \mathrm{S} \\
5: \mathrm{SS}\end{array}$ \\
\hline \multirow{3}{*}{$\begin{array}{l}\text { Menurut Flaherty } \\
\text { (2011:3) mentoring } \\
\text { adalah sebuah } \\
\text { kegiatan untuk } \\
\text { mendukung } \\
\text { seseorang dalam } \\
\text { mencapai tujuan } \\
\text { atau mengubah } \\
\text { seseorang untuk } \\
\text { melakukan } \\
\text { tindakan tertentu }\end{array}$} & \multirow{3}{*}{ Mentoring } & $\begin{array}{l}\text { Dukungan } \\
\text { psikologis } \\
\text { dan } \\
\text { emosional }\end{array}$ & $\begin{array}{ll}\text { - } & \text { seni mendengarkan, } \\
\text { - } & \text { memberikan dukungan } \\
\text { moral, } \\
\text { - } \\
\text { identifikasi masalah dan } \\
\text { memberikan dorongan, } \\
\text { memberikan hubungan yang } \\
\text { suportif }\end{array}$ & $\begin{array}{l}\text { Skala Likert } \\
1: \text { STS } \\
2: \text { TS } \\
3: \mathrm{N} \\
4: \mathrm{S} \\
5: \mathrm{SS}\end{array}$ \\
\hline & & $\begin{array}{l}\text { Bantuan } \\
\text { langsung } \\
\text { pengembanga } \\
\text { n akademik } \\
\text { mahasiswa }\end{array}$ & $\begin{array}{l}\text { - } \quad \text { kekuatan, } \\
\text { - } \quad \text { kelemahan, kemampuan } \\
\text { - } \quad \text { pembuatan perencanaan } \\
\quad \text { tujuan } \\
\text { - } \quad \text { pencapaian akademik }\end{array}$ & $\begin{array}{l}\text { Skala Likert } \\
1: \text { STS } \\
2: \text { TS } \\
3: \mathrm{N} \\
4: \mathrm{S} \\
5: \mathrm{SS}\end{array}$ \\
\hline & & Role model & $\begin{array}{ll}\text { - } & \text { pengalaman keberhasilan } \\
\text { mentor } \\
\text { - } \\
\text { pengalaman kegagalan } \\
\text { mentor }\end{array}$ & $\begin{array}{l}\text { Skala Likert } \\
1: \text { STS } \\
2: \text { TS } \\
3: \mathrm{N} \\
4: \mathrm{S} \\
5: \mathrm{SS}\end{array}$ \\
\hline
\end{tabular}

\section{METODE PENELITIAN}

Penelitian ini menggunakan pedekatan kuantitatif dengan jumlah sampel 275. Peneliti menggunakan teknik non probability sampling sebagai teknik pengambilan sampel yaitu teknik pengambilan sampel yang tidak memberi peluang/ kesempatan sama untuk setiap anggota populasi yang dipilih sebagai sampel (Sugiyono, 2013:120). Adapun kriteria sampel dalam penelitian ini adalah mahasiswa angkatan 2012 - 2014 dengan IPK 3,00-4, minimal melakukan kegiatan personal mentoring ke dosen PA sebanyak 3 kali selama 1 semester, dan mahasiswa jurusan manajemen Universitas Ciputra yang menempuh mata kuliah Entreprneurship/Entrepreneurial Project 
bersamaan dengan melakukan bisnis.Kriteria dosen pembimbing akademik dalam penelitian ini adalah dosen Universitas Ciputra yang sudah melakukan mentoring mahasiswa terkait dengan proses akademik mereka minimal 1 tahun terakhir. Keseluruhan populasi mahasiswa aktif jurusan Manajemen yaitu sebesar 1410 mahasiswa, namun hanya 968 mahasiswa saja yang memiliki IPK 3,00 - 4,00. Dengan demikian jumlah mahasiswa yang menjadi target populasi penelitian ini sebanyak 968 mahasiswa.Berdasarkan penelitian Krejcie dan Morgan (1970) tentang penentuan sampel yaitu untuk populasi 950 membutuhkan sampel sebanyak 274 sampel, dengan demikian peneliti menentukan banyaknya target sampel untuk penelitian ini yaitu sebesar 275 sampel.Keseluruhan penelitian ini menggunakan SPSS 20.0 sebagai media untuk membantu peneliti dalam proses penelitian.

Penelitian ini akan menguji pengaruh personal mentoring dosen PA terhadap prestasi mahasiswa pendidikan entrepreneurship.Variabel independent penelitian ini adalah fungsi mentoring yang terdiri dari dukungan psikologis dan emosional, bantuan pengembangan akademik dan sebagai role model.Prestasi akademik mahasiswa menjadi variabel dependen untuk penelitian ini karena terpengaruhi oleh fungsi mentoring dosen. Hal ini disebabkan karena definisi variabel dependen menurut Sugiyono (2013:59) adalah variabel yang dipengaruhi oleh variabel bebas.

\section{Teknik Analisis}

\section{Uji Validitas dan Reliabilitas}

Uji validitas dan reabilitas dilakukan peneliti untuk menguji layak atau tidaknya item pertanyaan yang diajukan kepada responden. Apabila dikatakan valid dan reliabel, maka penelitian dapat dilanjutkan ketahapan selanjutnya.

Uji validitas dilakukan dengan menggunakan rumus Pearson Product Moment. Dengan bantuan SPSS akan didapatkan hasil pengujian validitas dimana nilai validitas yang kuat jika koefisien korelasi (r) sama atau lebih besar dari 0,119 , namunapabila koefisien korelasi (r) kurang dari 0,119 maka instrumen tersebut dinyatakan tidak valid. Adapunnilai 0,119 ini dapat diperoleh melalui tabel Pearson Product Momentdengan tingkat kesalahan $(\alpha=0,05)$ dan jumlah sampel yang diambil $(n=275)$.

Hasil pengujian reliabilitas dapat dirumuskan bahwa suatu instrumen dikatakan handal apabila nilai Cronbach's alpha lebih besar atau sama dengan 0,119. Jika Cronbach's alpha lebih kecil dari 0,119 maka butir kuisioner tidak reliabel. Nilai 0,119 diperoleh dari tabel Pearson Product Momentdengan tingkat kesalahan $(\alpha=0,05)$ dan jumlah sampel yang diambil $(n=275)$

\section{Analisis Statistik Deskriptif}

Analisis ini digunakan peneliti untuk memberikan gambaran atau deskripsi empiris pada data yang dikumpulkan 
peneliti. Formula Capaian Indikator (CI) yang digunakan sebagai berikut:

$$
\begin{aligned}
C I= & \frac{\sum J R}{S I} \times 100 \% \\
& \text { Keterangan: } \\
& C I=\text { Capaian Indikator } \\
& \sum J R=\text { Jumlah jawaban } \\
& \text { responden } \\
& S I=\text { Skor ideal }
\end{aligned}
$$

Kriteria interpretasi untuk skor menurut Riduwan (2014:41) sebagai berikut:

$$
\begin{array}{ll}
\text { Angka } 0 \%-20 \% & : \text { Sangat Lemah } \\
\text { Angka } 21 \%-40 \% & : \text { Lemah } \\
\text { Angka } 41 \%-60 \% & : \text { Cukup } \\
\text { Angka } 61 \%-80 \% & : \text { Kuat } \\
\text { Angka } 81 \%-100 \% & \text { : Sangat Kuat }
\end{array}
$$

\section{Uji Asumsi Klasik}

Tahap uji asumsi klasik ini bertujuan untuk mengetahui apakah data-data yang digunakan sudah memenuhi syarat-syarat, dengan demikian sebelum melakukan analisis regresi. Adapun uji yang digunakan yaitu uji multikolinearitas, uji heteroskedastisitas, dan uji normalitas data.

\section{Regresi Linier Berganda}

Analisis Regresi Linear Berganda digunakan untuk mengestimasi variabel dependent sebagai akibat dari pengaruh tiga variabel independen. Model persamaan regresi berganda yang digunakan untuk tiga variabel yaitu sebagai berikut:

$$
Y=a+b_{1} X_{1}+b_{2} X_{2}+b_{3} X_{3}+\mathrm{e}
$$

\section{Keterangan:}

$Y$ adalah Prestasi Mahasiswa

$X_{1}$ adalah dukungan psikologis dan emosional
$X_{2}$ adalah bantuan langsung untuk pengembangan mahasiswa

$X_{3}$ adalah role model a adalah harga $\mathrm{Y}$ bila $\mathrm{X}=0$ (harga konstan)

$b_{i}$ adalah koefisien regresi

\section{Pengujian Hipotesis}

\section{Pengujian Hipotesis Simultan (Uji F)}

Penelitian ini menggunakan pengujian hipotesis Simultan menggunakan uji Fisher (uji F) dengan Analysis of Variance (ANOVA) untuk mengetahui pengaruh secara bersama antara variabel bebas terhadap variabel terikat. Rumus yang digunakan adalah sebagai berikut:

$$
F_{\text {hitung }}=\frac{J K R /(k-1)}{J K E /(n-k)}
$$

Keterangan:

$$
\begin{array}{ll}
F_{\text {hitung }} & =\text { Nilai Statistik Hitung } \\
J K R & =\text { Jumlah kuadrat regresi } \\
J K E & =\text { Jumlah kuadrat error } \\
k & =\text { Jumlah variabel } \\
n & =\text { Jumlah sampel } \\
l & =\text { Konstanta }
\end{array}
$$

Tingkat signifikansi $(\alpha)$ yang digunakan dalam penelitian ini adalah 0,05 atau 5\%. Hipotesis dan kaidah pengambilan keputusan adalah sebagai berikut:

Ho : bi $=0$; artinya bahwa secara simultan masing-masing variabel bebas tidak mempunyai pengaruh yang signifikan terhadap variabel terikat.

Ha : bi $\neq 0$ : artinya bahwa secara simultan masing-masing variabel bebas mempunyai pengaruh signifikan terhadap variabel terikat. 
Untuk menguji hipotesis dalam penelitian ini, digunakan statistik $\mathrm{F}$ dengan kriteria pengambilan keputusan yang akan diambil adalah sebagai berikut :

Dengan membandingkan nilai $F$ tabel dengan $\mathrm{F}$ hitung. Apabila Ftabel $>$ Fhitung, maka Ho diterima dan Ha ditolak, sedangkan apabila Ftabel < Fhitung, maka Ho ditolak dan Ha diterima.

Dengan menggunakan angka probabilitas signifikansi. Apabila probabilitas signifikansi $>0,05$, maka Ho diterima dan Ha ditolak, sedangkan apabila probabilitas signifikansi $<0,05$, maka Ho ditolak dan Ha diterima.

\section{HASIL DAN PEMBAHASAN}

Kegiatan belajar mengajar untuk pendidikan entrepreneurship cukup berbeda dengan perguruan tinggi lainnya di Indonesia. Kurikulum yang dipakai untuk pendidikan entrepreneurship berbasis kompetensi, karena mahasiswa akan melaksanakan proyek bisnis bersamaan dengan kegiatan kuliah. Banyak faktor yang akan membuat mahasiswa terlambat lulus terutama di perguruan tinggi berbasis entrepreneurship karena beratnya beban perkuliahan yang dipikulnya. Dengan demikian perlu adanya peran dosen PA yang dapat memonitor perkembangan akademik mahasiswa tersebut agar dapat mencapai prestasi akademik sesuai dengan kemampuan masing-masing mahasiswa. Berdasarkan hasil jawaban 275 responden, maka didapatkan hasil sebagai berikut:

\section{Uji Validitas dan Reliabilitas}

Uji validitas pertama dilakukan pada variabel Y, dimana pengambilan keputusan didasarkan pada nilai dari Tabel pearson Product-Momen untuk $n$ (jumlah data ) $=275$ dan $\alpha=0,05$ yaitu 0,119 . Jika nilai korelasi antara masing-masing pernyataan lebih dari 0,119 maka dapat disimpulkan bahwa pernyataan tersebut valid. Berdasarkan hasil di atas terlihat bahwa semua nilai korelasi lebih dari 0,119 (nilai pada Tabel Pearson) sehingga dapat dinyatakan bahwa semua pernyataan pada variabel Prestasi Mahasiswa dinyatakan valid. Oleh karena itu pengujian dapat dilanjutkan dengan uji reliabilitas dari semua pernyataan pada variabel Prestasi Mahasiswa.Uji reliabilitas dilakukan dengan membandingkan nilai Cronbach's Alpha dengan nilai pada Tabel korelasi Pearson yaitu 0,119. Berdasarkan uji Reliabilitas pada variabel Kinerja diperoleh koefisien Cronbach's Alpha 0,739 atau lebih besar dari 0,119 sehingga dapat disimpulkan bahwa, semua item pertanyaan yang digunakan pada variabel $\mathrm{Y}$ yaitu Prestasi Mahasiswa dinyatakan valid dan raliabel.

Uji validitas yang kedua dilakukan pada variabel $X_{1}$, dimana pengambilan keputusan didasarkan pada nilai dari Tabel pearson Product-Momen untuk $n$ (jumlah data ) $=275$ dan $\alpha=0,05$ yaitu 0,119 . Jika nilai korelasi antara masing-masing pernyataan lebih dari 0,119 maka dapat disimpulkan bahwa pernyataan tersebut valid. Berdasarkan hasil di atas terlihat bahwa semua nilai korelasi lebih dari 0,119 
(nilai pada Tabel Pearson) sehingga dapat dinyatakan bahwa semua pernyataan pada variabel dukungan psikologis dan emosional dosen PA dinyatakan valid. Oleh karena itu pengujian dapat dilanjutkan dengan uji reliabilitas dari semua pernyataan pada variabel dukungan psikologis dan emosional dosen.Uji reliabilitas dilakukan dengan membandingkan nilai Cronbach's Alpha dengan nilai pada Tabel korelasi Pearson yaitu 0,119. Berdasarkan uji Reliabilitas pada variabel Kinerja diperoleh koefisien Cronbach's Alpha 0,956 atau lebih besar dari 0,119 sehingga dapat disimpulkan bahwa, semua item pertanyaan yang digunakan pada variabel dukungan psikologis dan emosional dosen dinyatakan valid dan raliabel

Uji validitas yang kedua dilakukan pada variabel $X_{2}$ dimana pengambilan keputusan didasarkan pada nilai dari Tabel pearson Product-Momen untuk $n$ (jumlah data $)=275$ dan $\alpha=0,05$ yaitu 0,119 . Jika nilai korelasi antara masing-masing pernyataan lebih dari 0,119 maka dapat disimpulkan bahwa pernyataan tersebut valid. Berdasarkan hasil di atas terlihat bahwa semua nilai korelasi lebih dari 0,119 (nilai pada Tabel Pearson) sehingga dapat dinyatakan bahwa semua pernyataan pada variabel bantuan langsung untuk pengembangan mahasiswa dinyatakan valid. Oleh karena itu pengujian dapat dilanjutkan dengan uji reliabilitas dari semua pernyataan pada variabel bantuan langsung untuk pengembangan
mahasiswa.Uji reliabilitas dilakukan dengan membandingkan nilai Cronbach's Alpha dengan nilai pada Tabel korelasi Pearson yaitu 0,119. Berdasarkan uji Reliabilitas pada variabel Kinerja diperoleh koefisien Cronbach's Alpha 0,914 atau lebih besar dari 0,119 sehingga dapat disimpulkan bahwa, semua item pertanyaan yang digunakan pada variabel bantuan langsung untuk pengembangan mahasiswa dinyatakan valid dan raliabel

Uji validitas yang kedua dilakukan pada variabel $X_{3}$ dimana pengambilan keputusan didasarkan pada nilai dari Tabel pearson Product-Momen untuk $n$ (jumlah data $)=275$ dan $\alpha=0,05$ yaitu 0,119 . Jika nilai korelasi antara masing-masing pernyataan lebih dari 0,119 maka dapat disimpulkan bahwa pernyataan tersebut valid. Berdasarkan hasil di atas terlihat bahwa semua nilai korelasi lebih dari 0,119 (nilai pada Tabel Pearson) sehingga dapat dinyatakan bahwa semua pernyataan pada variabel Role Model dinyatakan valid. Oleh karena itu pengujian dapat dilanjutkan dengan uji reliabilitas dari semua pernyataan pada variabel Role Model.Uji reliabilitas dilakukan dengan membandingkan nilai Cronbach's Alpha dengan nilai pada Tabel korelasi Pearson yaitu 0,119. Berdasarkan uji Reliabilitas pada variabel Kinerja diperoleh koefisien Cronbach's Alpha 0,802 atau lebih besar dari 0,119 sehingga dapat disimpulkan bahwa, semua item pertanyaan yang digunakan pada variabel Role Model dinyatakan valid dan reliabel 
Analisis Statistik Deskriptif

Analisis Statistik Deskriptif Variabel

Prestasi Mahasiswa $(Y)$

Rata-rata Capaian Indikator untuk variabel Prestasi Mahasiswa sebesar 82,25 $\%$ dari rata-rata total skor jawaban responden sebesar 1130,9 dan rata-rata total Skor Ideal 1375. Capaian indikator tersebut menunjukkan bahwa Prestasi Mahasiswa pada Universitas Ciputra termasuk dalam kategori sangat baik yang diukur dari indikator - indikator yang telah disebutkan dalam kuesioner.

\section{Analisis Statistik Deskriptif Variabel}

Dukungan Psikologis dan Emosional $\left(X_{1}\right)$

Rata-rata capaian Indikator untuk
variabel Dukungan Psikologis dan Emosionalsebesar 81,43 \% dari rata-rata total skor jawaban responden sebesar 1119,667 dan rata-rata total Skor Ideal 1375. Dengan capaian indikator tersebut menunjukkan bahwa Dukungan Psikologis dan Emosional pada Universitas Ciputra termasuk dalam kategori sangat baik yang diukur dari indikator - indikator yang telah disebutkan dalam kuesioner.

\section{Analisis Statistik Deskriptif Variabel}

Bantuan Langsung Untuk

Pengembangan Mahasiswa $\left(X_{2}\right)$

Rata-rata Capaian Indikator untuk variabel Bantuan Langsung Untuk Pengembangan Mahasiswa sebesar 78,84\% dari rata-rata total skor jawaban responden sebesar 1184,067 dan rata-rata total Skor Ideal 1375. Dengan capaian indikator tersebut menunjukkan bahwa Bantuan Langsung Untuk Pengembangan Mahasiswa pada Universitas Ciputra termasuk dalam kategori baik yang diukur dari indikator - indikator yang telah disebutkan dalam kuesioner.

\section{Analisis Statistik Deskriptif Variabel $\boldsymbol{X}_{\mathbf{3}}$}

Rata-rata Capaian Indikator untuk variabel Role Model sebesar 79,27\% dari rata-rata total skor jawaban responden sebesar 1190 dan rata-rata total Skor Ideal 1375. Dengan capaian indikator tersebut menunjukkan bahwa Role Model pada Universitas Ciputra termasuk dalam kategori baik yang diukur dari indikator indikator yang telah disebutkan dalam kuesioner.

\section{Uji Asumsi Klasik}

Uji asumsi klasik bertujuan untuk mengetahui apakah data-data yang digunakan dalam analisis regresi sudah memenuhi syarat-syarat, dengan demikian sebelum melakukan analisis regresi, terlebih dahulu dilakukan uji multikolinearitas, uji heteroskedastisitas, dan uji normalitas data

\section{Uji Multikolinearitas}

Model persamaan Regresi Linear Berganda akan bebas dari masalah multikolinearitas, jika memiliki nilai Variance Inflation Factor (VIF) lebih kecil dari 10 dengan nilai toleransi lebih besar dari 0,1. Dalam kondisi di mana tidak ditemukan masalah multikolinearitas, maka 
Tabel 3.Tabel Uji Multikolinieritas

\begin{tabular}{|c|c|c|c|c|c|}
\hline & & & \multicolumn{3}{|c|}{ Coefficients $^{a}$} \\
\hline & & \multicolumn{2}{|c|}{ Unstandardized Coefficients } & \multicolumn{2}{|c|}{ Collinearity Statistics } \\
\hline \multicolumn{2}{|c|}{ Model } & $\mathrm{B}$ & Std. Error & Tolerance & VIF \\
\hline \multirow[t]{4}{*}{1} & (Constant) & 15.392 & .973 & & \\
\hline & $\mathrm{X} 1$ & .077 & .065 & .315 & 3.176 \\
\hline & $\mathrm{X} 2$ & .132 & .069 & .284 & 3.524 \\
\hline & X3 & .005 & .066 & .331 & 3.025 \\
\hline
\end{tabular}

a. Dependent Variable: $Y$ sebesar 3,025. Dari nilai VIF ketiga

Berdasarkan hasil Uji

Multikolinearitas diperoleh nilai Tolerance untuk variabel dukungan psikologis dan emosional $\left(X_{1}\right)$ sebesar $\mathbf{0 , 3 1 5}$, Variabel bantuan langsung untuk pengembangan mahasiswa $\left(X_{2}\right)$ sebesar $\mathbf{0 , 2 8 4}$, dan variabel Role Model $\left(X_{3}\right)$ sebesar 0,331. Dari nilai tolerance ketiga variabel bebas tersebut di atas, maka terbukti bahwa tidak ada yang kurang dari 0,10 atau di atas $10 \%$. Hasil perhitungan nilai VIF untuk variabel dukungan psikologis dan emosional $\left(X_{1}\right)$ sebesar 3,176, Variabel bantuan langsung untuk pengembangan mahasiswa $\left(X_{2}\right)$ sebesar 3,524 dan variabel Role Model $\left(X_{3}\right)$ variabel bebas tersebut di atas, maka diketahui bahwa tidak ada yang lebih dari 10. Dengan demikian, dapat disimpulkan bahwa antar variabel bebas dalam penelitian ini tidak terjadi multikolinearitas.

\section{Uji Heterokedastisitas}

Untuk mengukur gejala heterokedastisitas maka digunakan grafik Scatterplot antara nilai prediksi variabel terikat (ZPRED) dengan nilai residual (SDRESID). Jika dalam grafik Scatterplot terdapat pola tertentu maka dapat dikatakan bahwa ada gejala terjadinya heteroskedastisitas dalam data.

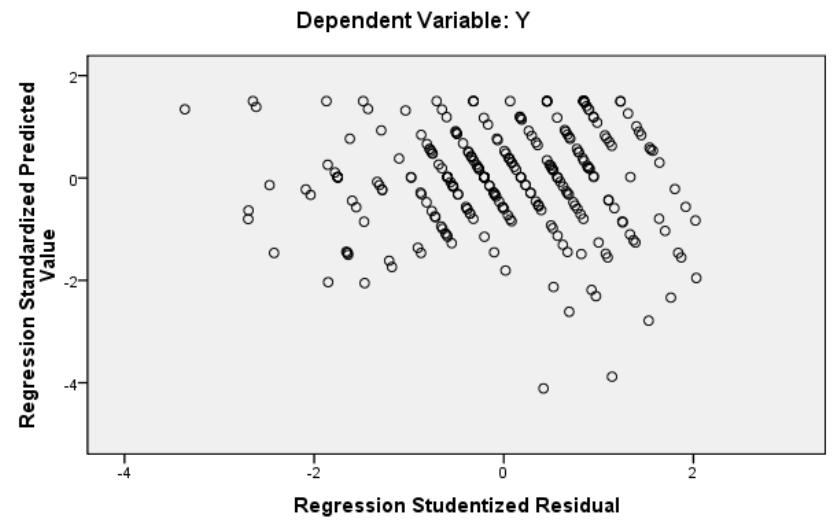

Gambar 2. Grafik Scatterplot hasil Uji Heterokedastisitas 
Berdasarkan hasil analisis data, dengan melihat persebaran data pada grafik Scatterplot maka terlihat bahwa titik-titik data di atas dan di bawah titik nol pada grafik Scatterplot bersifat menyebar dan tidak membentuk pola tertentu, atau dapat dikatakan bahwa pola yang dihasilkan bersifat random atau tidak teratur sehingga tidak menunjukkan adanya gejala

Normal P-P Plot of Regression Standardized Residual

Dependent Variable: $Y$

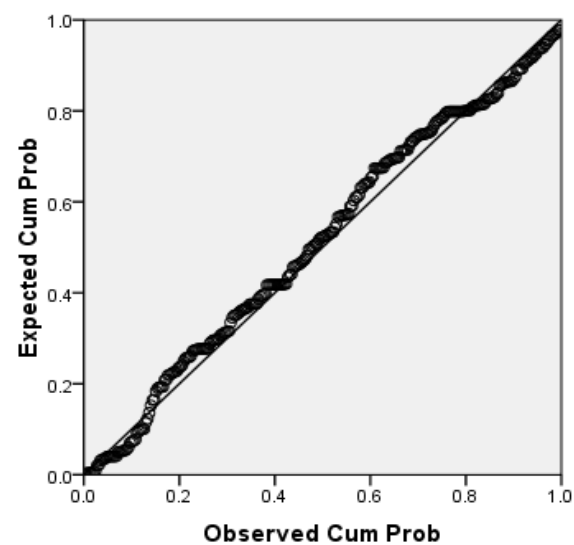

heteroskedastisitas.

\section{Uji Normalitas}

Untuk menguji normalitas dilakukan dengan melihat normal probability pilot yang membandingkan distribusi kumulatif dari data sesungguhnya dengan distribusi kumulatif dari distribusi normal. Untuk mengoperasikannya dipergunakan komputer program SPSS 20.0.

Histogram

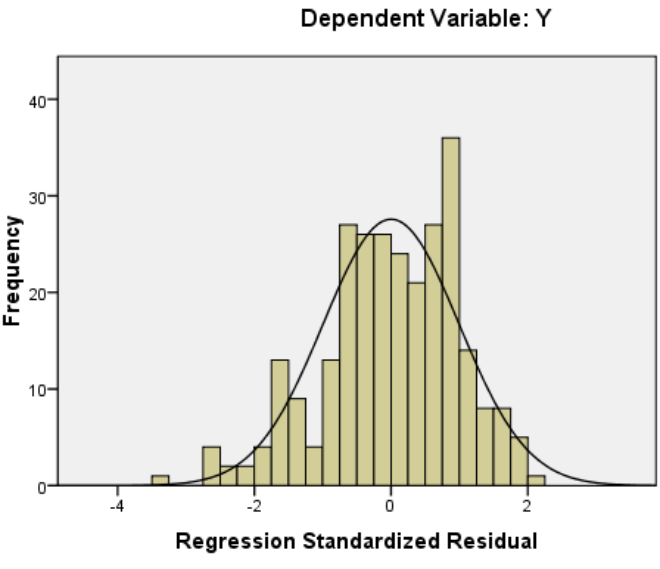

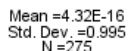

Hasil di atas maka dapat disimpulkan bahwa data telah berdistribusi normal. Hal ini telihat dari P-P plot dimana bahwa titiktitik data mengikuti garis lurus, sedangkan pada histogram terlihat bahwa dimana data yang diplot mengikuti lonceng atau grafik distribusi normal. Berdasarkan dua grafik di atas dapat disimpulkan bahwa data berdistribusi normal dan dapat diolah lebih lanjut.

\section{Regresi Linear Berganda}

Analisis Regresi Linear Berganda digunakan untuk mengestimasi variabel dependent sebagai akibat dari pengaruh tiga variabel independent. Output yang dihasilkan dari Software SPSS 20.0 adalah sebagai berikut 
Coefficients $^{a}$

Tabel 4 Tabel Hasil Regresi Linier Berganda

\begin{tabular}{|ll|r|r|r|}
\hline \multirow{2}{*}{ Model } & \multicolumn{2}{|c|}{ Unstandardized Coefficients } & \multicolumn{2}{c|}{ Standardized Coefficients } \\
\cline { 2 - 5 } & (Constant) & \multicolumn{1}{|c|}{ B } & Std. Error & Beta \\
\hline 1 & 15.392 & .973 & \\
\\
X1 & .077 & .065 & .122 \\
X2 & .132 & .069 & .206 \\
X3 & .005 & .066 & .008 \\
\hline
\end{tabular}

a. Dependent Variable: $Y$

Berdasarkan hasil analisis regresi linear berganda, diperoleh persamaan sebagai berikut:

$Y=15,392+0,077 X_{1}+0,132 X_{2}+0,005 X_{3}$. Berdasarkan persamaan di atas, maka interprestasi untuk masing-masing koefisien regresi dapat uraikan sebagai berikut:

Konstanta (a) : 15,392. Angka atau konstanta ini menjelaskan bahwa jika semua variabel bebas (dalam hal ini dukungan psikologis dan emosional $\left(X_{1}\right)$, bantuan langsung untuk pengembangan mahasiswa $\left(X_{2}\right)$ dan Role Model $\left.\left(X_{3}\right)\right)$ diasumsikan konstan atau perubahannya nol maka variabel Kinerja Pegawai $(Y)$ sebesar $\mathbf{1 5 , 3 9 2 .}$

\section{Koefisien Regresi Variabel Kepuasan}

Kerja $\left(b_{1}\right)=\mathbf{0 , 0 7 7}$. Koefisien regresi ini menjelaskan bahwa jika variabelvariabelbantuan langsung untuk pengembangan mahasiswa $\left(X_{2}\right)$ danRole Model $\left(X_{3}\right)$ dianggap konstan atau tetap serta terjadi perubahan (kenaikan) pada variabeldukungan psikologis dan emosional $\left(X_{1}\right)$ sebesar satu satuan maka akan mengakibatkan peningkatan variabel Prestasi Mahasiswa $(Y)$ sebesar 0,077satuan. Demikian pula sebaliknya, jika terjadi penurunan pada variabeldukungan psikologis dan emosional $\left(X_{1}\right)$ sebesar satu satuan maka akan mengakibatkan penurunan variabel Prestasi Mahasiswa $(Y)$ sebesar 0,077satuan.

\section{Koefisien Regresi Variabel Kompetensi}

Individu $\left(\boldsymbol{b}_{\mathbf{2}}\right)=\mathbf{0 , 1 3 2}$. Koefisien regresi ini menjelaskan bahwa jika variabelvariabeldukungan psikologis dan emosional $\left(X_{1}\right)$ danRole Model $\left(X_{3}\right)$ dianggap konstan atau tetap serta terjadi perubahan (kenaikan) pada variabelbantuan langsung untuk pengembangan mahasiswa $\left(X_{2}\right)$ sebesar satu satuan maka akan mengakibatkan kenaikan variabel Prestasi Mahasiswa $(Y)$ sebesar $\mathbf{0 , 1 3 2}$ satuan. Demikian pula sebaliknya, jika terjadi penurunan pada variabel bantuan langsung untuk pengembangan mahasiswa $\left(X_{2}\right)$ sebesar satu satuan maka akan mengakibatkan penurunan variabel Prestasi Mahasiswa $(Y)$ sebesar 0,132satuan.

\section{Koefisien Regresi Variabel Dukungan} Organisasi $\left(\boldsymbol{b}_{3}\right)=\mathbf{0 , 0 0 5}$. Koefisien regresi ini menjelaskan bahwa jika variabelvariabeldukungan psikologis dan emosional $\left(X_{1}\right)$ danbantuan langsung untuk pengembangan mahasiswa $\left(X_{2}\right)$ dianggap 
konstan atau tetap serta terjadi perubahan (kenaikan) pada variabelRole Model $\left(X_{3}\right)$ sebesar satu satuan maka akan mengakibatkan kenaikan variabel Prestasi Mahasiswa $(Y)$ sebesar $\mathbf{0 , 0 0 5}$ satuan. Demikian pula sebaliknya, jika terjadi penurunan pada variabelRole Model $\left(X_{3}\right)$ sebesar satu satuan maka akan mengakibatkan penurunan variabel Prestasi Mahasiswa $(Y)$ sebesar $\mathbf{0 , 0 0 5}$ satuan.

\section{Pengujian Hipotesis}

\section{a. Pengujian Hipotesis Simultan (Uji F)}

Pengujian hipotesis Simultan menggunakan uji Fisher (uji F) dengan Analysis Of Variance (ANOVA) untuk mengetahui pengaruh secara bersama antara variabel bebas terhadap variabel terikat. Tingkat signifikansi $(\alpha)$ yang digunakan dalam penelitian ini adalah 0,05 atau 5\%. Hipotesis dan kaidah pengambilan keputusan adalah sebagai berikut:
Ho : bi $=0$; artinya bahwa secara simultan masing-masing variabel bebas tidak mempunyai pengaruh yang signifikan terhadap variabel terikat.

Ha : bi $\neq 0$ : artinya bahwa secara simultan masing-masing variabel bebas mempunyai pengaruh signifikan terhadap variabel terikat.

Untuk menguji hipotesis dalam penelitian ini, digunakan statistik $\mathrm{F}$ dengan kriteria pengambilan keputusan yang akan diambil adalah sebagai berikut menggunakan angka probabilitas signifikansi. Apabila probabilitas signifikansi $>0,05$, maka Ho diterima dan Ha ditolak. Sedangkan apabila probabilitas signifikansi $<0,05$, maka Ho ditolak dan Ha diterima. Output yang dihasilkan dari Software SPSS 20.0 adalah sebagai berikut.

Tabel 5.Tabel Anova ANOVA $^{\mathrm{D}}$

\begin{tabular}{|ll|r|r|r|r|r|}
\hline Model & & Sum of Squares & df & Mean Square & F & Sig. \\
\hline 1 & Regression & 206.677 & 3 & 68.892 & 10.214 & $.000^{\text {a }}$ \\
& Residual & 1827.920 & 271 & 6.745 & & \\
& Total & 2034.596 & 274 & & & \\
\hline
\end{tabular}

a. Predictors: (Constant), X3, X1, X2

b. Dependent Variable: $Y$

Berdasarkan hasil perhitungan uji $\mathrm{F}$ diperolah Fhitung $=\mathbf{1 0 , 2 1 4}$ dengan nilai signifikan 0,000 lebih kecil dari tingkat signifikan yang digunakan yaitu 0,05 atau 5\%, maka keputusannya adalah menerima hipotesisal ternatif $\left(H_{a}\right)$ dan menolak hipotesis nol $\left(H_{0}\right)$. Artinya variabel dukungan psikologis dan emosional $\left(X_{1}\right)$, bantuan langsung untuk pengembangan mahasiswa $\left(X_{2}\right)$ dan role model $\left(X_{3}\right)$ secara bersama-sama mempunyai pengaruh signifikan terhadap Prestasi Mahasiswa $(Y)$ pada Universitas Ciputra.

\section{Analisis Koefisien Determinasi}

Koefisien determinasi digunakan untuk mengetahui besaran persentase kontribusi tiga variabel independen secara simultan terhadap prestasi mahasiswa. Nilai 
$R^{2}$ yang mendekati nol berarti kemampuan semua variabel bebas dalam menjelaskan variabel terikat sangat rendah. Sebaliknya nilai $R^{2}$ yang mendekati satu berarti semua variabel bebas memberikan hampir semua informasi yang dibutuhkan untuk memprediksi variasi variabel terikat.Output yang dihasilkan dari Software SPSS 20.0 adalah sebagai berikut.

Tabel 6. Tabel Analisis Koefisien Determinasi

Model Summary ${ }^{\mathrm{b}}$

\begin{tabular}{|l|r|r|r|c|}
\hline Model & $\mathrm{R}$ & $\mathrm{R}$ Square & Adjusted R Square & $\begin{array}{c}\text { Std. Error of the } \\
\text { Estimate }\end{array}$ \\
\hline 1 & $.319^{\mathrm{a}}$ & .102 & .092 & 2.59713 \\
\hline
\end{tabular}

a. Predictors: (Constant), X3, X1, X2

b. Dependent Variable: $Y$

Berdasarkan hasil di atas terlihat bahwa nilai Koefisien Determinasi $\left(\mathrm{R}^{2}\right)$ sebesar 0,102. Nilai tersebut berarti bahwa kontribusi atau sumbangan variabel bebas dalam penelitian ini yaitu dukungan psikologis dan emosional $\left(X_{1}\right)$, bantuan langsung untuk pengembangan mahasiswa $\left(X_{2}\right)$ dan role model $\left(X_{3}\right)$ terhadap Prestasi Mahasiswa $(Y)$ pada Universitas Ciputra sebesar $\mathbf{1 0 , 2 \%}$ dan sisanya $\mathbf{8 9 , 8 \%}$ dipengaruhi oleh faktor-faktor lain yang tidak termasuk sebagai variabel dalam penelitian ini.

\section{SIMPULAN DAN SARAN}

Banyak faktor yang bisa membuat mahasiswa tidak lulus tepat waktu dapat dicegah dan dimonitor oleh dosen PA. Kegiatan ini diharapkan dapat memotivasi mereka dalam mencapai target mereka masing-masing. Dosen PA mendukung mahasiswanya dengan kegiatan yang dilakukan melalui mentoring akademik. Kegiatan mentoring ini dalam bentuk dukungan psikologis dan emosional, bantuan langsung pengembangan akademik, dan role model sehingga mahasiswa dapat mencapai prestasi sesuai dengan kemampuan mereka masingmasing. Penelitian ini dilakukan juga sebagai wujud evaluasi pelaksanaan mentoring dosen pembimbing akademik (dosen PA) terhadap mahasiswanya, terutama di lingkungan pendidikan entrepreneurship yang mahasiswa diarahkan melakukan kegiatan bisnis bersamaan dengan kuliah.

Berdasarkan hasil perhitungan uji $\mathrm{F}$ diperolah Fhitung $=10,214$ dengan nilai signifikan 0,000 lebih kecil dari tingkat signifikan yang digunakan yaitu 0,05 atau 5\%, maka keputusannya adalah menerima hipotesisal ternatif $\left(H_{a}\right)$ dan menolak hipotesis nol $\left(H_{0}\right)$. Artinya variabel dukungan psikologis dan emosional $\left(X_{1}\right)$, bantuan langsung untuk pengembangan mahasiswa $\left(X_{2}\right)$ dan role model $\left(X_{3}\right)$ secara bersama-sama mempunyai pengaruh signifikan terhadap Prestasi Mahasiswa $(Y)$ pada Universitas Ciputra. Hasil tersebut memperkuat penelitian yang dilakukan 
peneliti sebelumnya secara kualitatif bahwa dosen PA sangat berperan dalam perkembangan prestasi akademik mahasiswa (Pranatasari, 2014). Melalui kegiatan mentoring, seseorang dapat mengubah seseorang lain sesuai dengan target capaian masing-masing, dalam hal ini dosen PA dapat mengubah mahasiswa dalam bentuk motivasi untuk mencapai tujuan sesuai dengan yang diharapkannya. Melalui proses dukungan psikologis dan emosional, dosen PA berperan dalam mendengarkan cerita mahasiswa untuk memberikan dukungan moral, mengidentifikasi masalah mahasiswa untuk membantu memberikan solusi sehingga tercipta suatu hubungan yang suportif untuk mencapai prestasi akademik. Melalui proses bantuan langsung pengembangan akademik, dosen PA memberi pengarahan terkait akademik seperti skema perkuliahan dari semester satu hingga lulus, identifikasi kemampuan untuk mencapai target, dan identifikasi kekuatan dan kelemahan untuk mendukung pencapaian prestasi akademik. Melalui proses penciptaan role model, dosen PA dapat membagikan pengalaman keberhasilannya serta kegagalan yang pernah dialaminya untuk memotivasi mahasiswa lebih baik lagi.

Keterbatasan penelitian ini adalah sampel mahasiswa masih dalam lingkup Universitas Ciputra saja. Peneliti menyarankan supaya penelitian ini dilakukan ke beberapa perguruan tinggi sehingga dapat bermanfaat untuk menyadarkan dosen wali akan pentingnya peran mereka bagi masa depan mahasiswa maupun negara.

\section{DAFTAR PUSTAKA}

Ackerman, D.S, Gross B.L. (2005). "My instructor made me do it: task characteristic of procrastination.".Journal of Marketing Education. Vol.27, No 1, 5-13.

\section{Anonim, (2014).Seputar Penasihat Akademik atau Dosen Wali.http://www.kopertis12.or.id/2012 /10/14/seputar-penasihat-akademik- atau-dosen-wali.html . Diakses tanggal 17 Juni 2015}

Cook, Marshall J, Laura Poole. (2011). Effective Coaching. United States: mc. Graw Hill Companies.

Crisp, Gloria ; Irene Cruz, (2009). Mentoring College Students: A Critical Review of the Literature Between 1990 and 2007. Research in Higher Education. pp 525-545.

Flaherty, James. (2010). Coaching: Evoking Excellence in Others. USA: Routledge.

Kaltim Post. (2012). Unmul Sumbang "kerugian" Rp77M untuk 4287 Mahasiswa Tak Aktif Perkuliahan.http://www.kaltimpost.co. $\mathrm{id} /$ berita/detail/6393/unmul-sumbangkerugian-rp-77-m.html. Diakses tanggal 17 Juni 2015

Komarraju, Meera ; Sergey Musulkin ; Gargi Bhattacharya (2010). Role of Student - Faculty Interactionsin Developing College Students Academic Self Concept, Motivation, and Achievement.Journal of College Student Development.pp 51.

Saliniti, Geri. (2005).The Effect of Formal Mentoring on the Retention rates for First Year Low Achieving Student. Canadian Journal of Education. Pp 853-873. 
Sugiyono.(2013). Metode Penelitian Bisnis. Bandung: Alfabeta.

Sullivan, Robert, (2000). Entrepreneurial Learning and Mentoring.International Journal of Entrepreneurial Behavior $\&$ Research. Vol 6 no 3 pp 160-175

Sumpeno, Wahyudin. (2009). Menjadi Fasilitator Genius. Yogyakarta: Pustaka Pelajar.

Suryana. (2013). Kewirausahaan: Kiat dan Proses Menuju Sukses. Jakarta: Salemba Empat.

Taylor, Christine; Jay C Taylor, dan james $\mathrm{K}$ Stoller (2009). The Influence of
Mentorship and Role Modelling on Developing Physician-Leaders: Views of Aspiring and Established Physician-Leaders. .pp.1130-1134

Thompson, Lynn A; Lisa Kelly Vance, (2001).The Impact of Mentoring on AcademicAchievement of Risk Youth.Children and Youth Services Review. Vol 23. No 3 pp 227-242.

Winardi.(2003). Entrepreneur dan Entrepreneurship. Jakarta: Prenadamedia Group. 